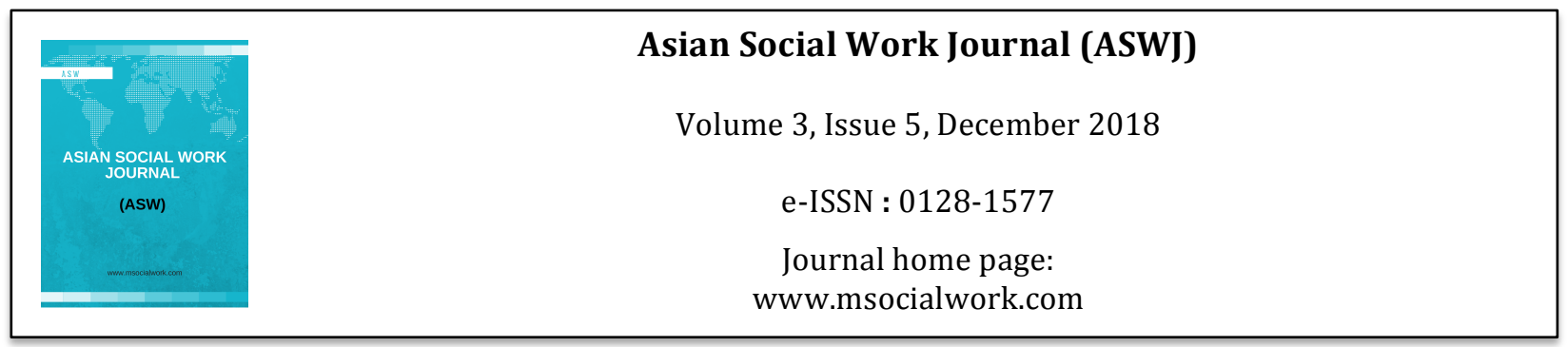

\title{
The Experiences of Disadvantages and Discrimination Among the Tea Garden Workers in Bangladesh: An Overview
}

\author{
Md Abdul Jalili ${ }^{1}$, Mohammad Ali Oakkas ${ }^{1}$ \\ ${ }^{1}$ Department of Social Work, Shahjalal University of Science and Technology \\ Corrrespondence: Md Abdul Jalil (jalil-scw@sust.edu)
}

\begin{abstract}
This paper aims to understand the experiences of disadvantages and discrimination among tea garden workers in Bangladesh. Based on the interviews of 75 tea garden workers, the paper identified few domains where they experience disadvantage and discrimination. The paper recommended government intervention and NGO and INGO initiatives to ensure educational opportunities for their children, provide healthcare facilities and increase wages for the garden workers. The paper has implications for the international community to ensure equitable society and social justice for the vulnerable and minority groups all over the world.
\end{abstract}

Key words: tea garden workers, disadvantages, discrimination, Bangladesh

\section{Introduction}

Sylhet is a major tea producing area in Bangladesh where a large number of low-income workers involved with the industry from generation to generation for their livelihood (Ahmed, Begum, \& Chowdhury, 2010). There are 162 tea gardens in Bangladesh (Al-Amin, Hossain, \& Parveen, 2017) and most of them situated in the Sylhet. Tea garden workers originally migrated from Assam and other states of India and Myanmar. They have been living mostly in the Sylhet region of Bangladesh since the mid-Eighteenth century (Ahmed et al., 2010). Tea gardens significantly contributed to the national economy of the country by generating employment opportunities, increasing foreign export and reducing poverty. A study shows that around 358,550 workers are employed in the tea gardens in Bangladesh, and 75\% of them are women (Saha, 2010, cited in Chowdhury, Hasan, \& Karim, 2011).

Tea garden laborers possess distinct cultural traditions significantly different from mainstream Bangladeshi people. Their social interactions are limited with themselves. Thus, they are deprived of access to education, health care, employment, and other social amenities and facilities compared to the mainstream Bangladeshi counterpart (Hossain, Al-Amin, \& Parveen, 2017). A study shows the overall multiple deprivation scores in the tea gardens is 0.541 that is 1.57 times higher than the average national deprivation scores in Bangladesh (Barkat et al., 2010). Therefore, it is worthwhile to conduct empirical studies to uncover their experiences of disadvantages and discrimination so that effective measures can be taken to uphold their equal access to the social amenities and facilities which are available for the citizens of Bangladesh. 


\section{Review of Literature}

Studies depicted the miserable human rights condition of tea garden workers in Bangladesh. For example, Das and Islam (2006) revealed the deplorable conditions of human rights of the tea garden workers. Based on interview and observation method, the authors found that tea garden workers in Bangladesh are deprived of getting access to education, health care, and other fundamental rights. Notably, children are affected significantly, as limited access to education, in turn, restrict their capacity development. Therefore, options to choose a profession other than tea industry have been restricted for them. In addition, most of the workers had to work in the gardens with a meager wage that force them to remain within the circle of poverty. Hossain et al. (2017) investigated how the rights of children are protected in the tea gardens of Bangladesh. The authors observed that children living in the tea gardens are deprived of fundamental human rights because of the poor socio-economic condition of the families, limited access to education, healthcare, and social services. However, this study unearths only the rights of children. The areas where tea garden workers are discriminated and disadvantaged remain unexplored.

Al-Amin et al. (2017) conducted a study on the poverty situation and social exclusion among tea garden workers in Bangladesh. The researchers opined that tea garden workers do not have access to work outside the tea garden due to distant geographical locations and compulsion to work in the tea industry. Consequently, they ended up with meager income by which it is difficult to lead a decent livelihood. Therefore, they also being excluded from access to many social opportunities and services compared to the mainstream Bengali population living in the surrounding areas. In addition, tea garden workers also are alienated from the mainstream community as they strongly inclined to practice their distinct sub-culture and do not feel comfortable to extend their social interaction beyond their community.

Ahmed et al. (2010) reported the worse condition of the sanitary system in the tea gardens in Bangladesh. The researchers viewed that financial hardship and illiteracy of the tea garden workers are responsible for the problems in the sanitary system. Tea garden workers do not have adequate knowledge about personal healthcare and hygiene. It is claimed that around $50 \%$ of the tea gardeners practice open defecation system instead of the lavatory and they do not wash hands after toileting. In addition, the prevalence of superstitions is also partly responsible for sanitation problem. Chowdhury et al. (2011) revealed the deplorable condition of water supply, waste management and sanitation system for the tea garden workers. The study further argued that it is not possible for the gardeners to solve their problems and improve the quality of the services by themselves as they work with a meager wage. They are also deprived of education and healthcare facilities.

\section{Objectives of the Study}

The general objective of this study is to uncover the scenario of disadvantages and discrimination among tea garden workers in Bangladesh. Towards this end, the study adopted the following specific objectives:

i. To know the socio-economic condition of tea garden workers.

ii. To understand their educational status and scenario of education among the children

iii. To unearth the healthcare facilities of the gardeners

iv. To uncover their participation in the political process of the country.

\section{Methodology}

This study is descriptive. The respondents were selected from the Malnichara tea garden, Sylhet, Bangladesh. The purposive sampling procedure was adopted to recruit the respondents considering the convenience of the researcher, and time and financial constraints. 
The survey method was used to collect the necessary data to understand the disadvantaged condition of the tea garden workers. The respondents were interviewed using a structured questionnaire. One respondent was selected from each family. We preferred the household head for the interview. Nevertheless, additional members of the family were often participated in the interview to assist the selected participant if it deemed needed. Some of the respondents were also showed interest to consult other family members for the better understanding of a particular issue. Data were analyzed using statistical methods.

\section{Demographic profile}

The findings of the study show that middle-aged workers dominated in the tea gardens (Table- 1 ). The workers are a mix of different age groups. However, most of the respondents (38.67\%) are from the age group of 31-40 years. A significant number of workers $(9.33 \%)$ are more than 60 years old. Young workers are also found in the study area $(10.67 \%)$.

Table-1: Age of the respondents

\begin{tabular}{lll}
\hline Age & Frequency & Percentage (\%) \\
\hline $20-30$ & 8 & 10.67 \\
$31-40$ & 29 & 38.67 \\
$41-50$ & 18 & 24 \\
$51-60$ & 13 & 17.33 \\
60 and more & 7 & 9.33 \\
\hline Total & $\mathbf{7 5}$ & $\mathbf{1 0 0}$ \\
\hline (Source: Field Survey, April-July, 2014) &
\end{tabular}

Among the respondents, only 2.67 percent are unmarried (Table 2). It is observed that most of them got married at an early age compared to the mainstream Bengali people. It is also known that tea garden workers follow the traditional system of choosing the partner and arranging the marriage. The family has the fundamental responsibility of choosing the bride or the bridegroom. The family also arranges the ceremony and bears all the cost associated with the marriage ceremony.

Table-2: Marital status

\begin{tabular}{lll}
\hline Marital Status & Frequency & Percentage (\%) \\
\hline Married & 71 & 94.67 \\
Unmarried & 2 & 2.67 \\
Widower & 1 & 1.33 \\
Widow & 1 & 1.33 \\
\hline Total & $\mathbf{7 5}$ & $\mathbf{1 0 0}$ \\
\hline
\end{tabular}

(Source: Field Survey, April-July, 2014)

Nuclear families exist among most of the tea garden labors. It is interesting that traditional joint families dominate the mainstream Bangladeshi people, though the opposite scenario exists among the tea gardeners. The main reason is that everyone has to work among the tea garden communities. Even a child has to start work if s/he stops the study. Therefore, dependent and unemployed persons among them are very rare. Despite the abundance of nuclear families, family size is high (Table 3 ) among the workers of tea gardens.

Table-3: Family size

\begin{tabular}{lll}
\hline Number of family members & Frequency & Percentage $(\%)$ \\
\hline $1-4$ & 11 & 14.33 \\
$5-6$ & 46 & 61.33 \\
$7-8$ & 15 & 20.00 \\
\hline
\end{tabular}




\begin{tabular}{lll}
\hline $9+$ & 3 & 4.00 \\
\hline Total & $\mathbf{7 5}$ & $\mathbf{1 0 0}$ \\
\hline
\end{tabular}

(Source: Field Survey, April-July, 2014)

\section{Education}

"We are here for work, not for education. The authority does not want to educate us" - this statement of a participant represents the underlying factors why literacy rate is quite low among the gardeners compared to the national rate of literacy in Bangladesh. The findings of the study illustrated that half of the research participants (48\%) are illiterate (Table 4). They were deprived of accessing education institutions. The abject poverty, non-availability of schools close to their home, the unwillingness of family members especially parents and non-understanding the benefits of education are the factors why they did not have access to the formal education. In addition, garden owners and authority is not interested in making such an arrangement so that tea garden children get the opportunity to education.

Table-4: Educational status

\begin{tabular}{lll}
\hline Educational Status & Frequency & Percentage (\%) \\
\hline Illiterate & 36 & 48.00 \\
0 to Grade 5 & 30 & 40.00 \\
6 to Grade 10 & 4 & 10.67 \\
Grade 11 & 1 & 1.33 \\
\hline Total & 75 & 100 \\
\hline
\end{tabular}

(Source: Field Survey, April-July, 2014)

The study findings show an alarming situation of formal education among tea garden workers. Among the participants, only one $(1.33 \%)$ had a chance to complete the education at grade 11 . Only 10.67 percent workers completed the five-year primary education, and few of them studied at the secondary level. It is observed that completion of five-year primary education is comparatively better as there is a government primary school in the garden. A national NGO, BRAC, also runs a primary school in the Malnichara tea garden. However, most of the students dropped out of education after completing primary school due to family poverty and geographical distance of secondary schools. The similar condition of education is also observed among the family members of the tea garden workers (Table 5).

Table-5: Educational status of the family members.

\begin{tabular}{|c|c|c|}
\hline $\begin{array}{l}\text { Family members level of } \\
\text { education }\end{array}$ & Frequency & Percentage (\%) \\
\hline Illiterate & 69 & 20.33 \\
\hline 0 to Grade 5 & 184 & 53.96 \\
\hline 6 to Grade 10 & 63 & 18.47 \\
\hline Grade 11 & 4 & 1.17 \\
\hline Total & 341 & 100 \\
\hline
\end{tabular}

(Source: Field Survey, April-July, 2014)

It seemed that most of the parents are not conscious about the education of their children. They consider to employ the child in the tea garden is more beneficial to them than the education. However, one parent said, "children are not eager to go to school." Nevertheless, what they did to encourage children for the education remains unknown to us.

\section{Economic Affairs}

The results of the study demonstrated that the monthly income of the tea garden workers is much lower to maintain a decent living. They had to work from dawn to dusk but paid very low, and therefore, they ended up with extreme poverty. During the interview, 96 percent of the respondents have mentioned that the wage they received from their employment is not sufficient to mitigate the family needs. 
According to the figure - 6, around 32 percent of the respondents earn less than Tk. 5000 monthly which is not sufficient for the survival let alone fulfilling the health, education and other fundamental needs. Only 9.33 percent of the workers earn Tk. 10000 or more.

Table-6: Monthly income

\begin{tabular}{lll}
\hline Income (TK.) & Frequency & Percentage (\%) \\
\hline $2000-4000$ & 14 & 18.66 \\
$4001-6000$ & 25 & 33.33 \\
$6001-8000$ & 20 & 26.67 \\
$8001-10000$ & 9 & 12 \\
10000 and more & 7 & 9.33 \\
\hline Total & 75 & 100 \\
\hline
\end{tabular}

(Source: Field Survey, April-July, 2014)

Tea garden workers start their work at 9.00 in the morning and finish at 5.00 in the evening. However, they often had to stay in the garden a few more hours as they need to fill the quota of the day. It is known that every worker had to pick $20 \mathrm{~kg}$ tea leaf from the garden in a day. Their salary is deducted if someone is unable to fill the quota in a particular day. Some of the gardeners work as a carpenter and pump driver and receive Tk. 55 a day. The wage they receive is inhumane even comparing to the other sector of the country. In addition to the monthly wage, every worker receives $5 \mathrm{~kg}$ rice per month and free accommodation. Nevertheless, the accommodation lacks essential amenities and facilities. Moreover, there is no privacy, as 3 to 4 people often had to live in a small room.

Another form of discrimination in the tea gardens is the entitlement of holidays. Usually, workers can enjoy public holidays. However, holidays can be enjoyed without pay. Women workers are entitled to enjoy parental leave for four months. However, they are not paid for the period of leave.

It is already mentioned that unemployment and dependency rate is quite low among the tea garden community. Everyone in the labor force is involved in economic activities, though their wage is too low. Most of the workers do overtime work to earn some additional money as it is hard to maintain the family with their wages. Those who cannot work in the garden cultivate vegetable at the surroundings of the house. They also rear domestic animals such as cow, goat, chicken, etc. for securing additional money for the family.

Child labor also exists among them. Children work in the garden as well as nearby areas as driving small vehicles, tea boy in the restaurants, etc. As we said that the dropout rate is higher among the children, parents engaged them in the garden to work once they stopped going to school. Most of the parents do not encourage their children to continue education after completion of primary school. Such apathy of parents is because of the distant geographical location of the school and also for getting additional money to family income. During the interview, 34 participants (45.34\%) acknowledged that one or more children in their families work full time. However, it is known that child workers do not get wage equal to the adult members of the garden. Children are employed as a temporary worker and paid Tk. 50 a day. Temporary workers are also not entitled to receive other benefits provided by the garden authority such as housing, ration, bonus, healthcare facilities, etc.

The study indicates that, among the child laborers, boys are higher than the girls in the garden (Table 7). It is understood that female children can work only in the garden. However, male children can work in the garden as well as nearby rubber garden, and some other jobs nearby the tea gardens. That is why the dropout rate among male children is high.

Table-7: Status of children according to sex

\begin{tabular}{lllll}
\hline Sex & Studying & Working & Newborn baby & Total \\
\hline Male & $48(30.62 \%)$ & $43(12.91 \%)$ & $13(6.22 \%)$ & $104(49.75 \%)$ \\
\hline
\end{tabular}




\begin{tabular}{lllll}
\hline Female & $70(33.49 \%)$ & $18(8.61 \%)$ & $17(8.13 \%)$ & $105(50.23 \%)$ \\
\hline Total & $134(64.11 \%)$ & $45(21.52 \%)$ & $30(14.35 \%)$ & $209(100 \%)$ \\
\hline
\end{tabular}

(Source: Field Survey, April-July, 2014)

\section{Access to Healthcare}

Tea garden authority offers many of welfare provisions only to the permanent employees. The temporary workers who are approximately half of the total workers are not entitled to receive any such benefits (Al-Amin et al., 2017). Permanent workers and their family members are entitled to receive free medical services in the local medical center. Primary healthcare services and some common medicines are provided in the local medical center. In case of the critical condition of the patients, they refer to the Osmani Medical College Hospital. Tea gardeners may also have access to the government hospital in the Sylhet city in case of emergency or if the condition of the patient is serious.

The services in the local medical center are not satisfactory (46.67\%) to most of the respondents (Table 8 ). They are not happy with the services due to the absence of qualified doctors, not providing medicine, misbehavior of doctors, nurses and other staffs, etc. There is a saying among the tea gardeners that "there is only one specific medicine in the medical center and it is prescribed no matter whatever disease you have." However, about 33 percent of the respondents are happy with the services they received from the local medical center of the garden. Nevertheless, tea garden authority does not take the responsibility of the workers who are unable to work because of the occupational hazards of accidents.

Table-8: Condition of medical care

\begin{tabular}{lll}
\hline Condition & Frequency & Percentage (\%) \\
\hline Satisfactory & 25 & 33.33 \\
Not satisfactory & 35 & 46.67 \\
Some extent good & 10 & 13.33 \\
\hline Total & 75 & 100 \\
\hline
\end{tabular}

(Source: Field Survey, April-July, 2014)

It is known that tea gardeners prefer traditional healers for the treatment of general diseases. They consulted Kabiraj who often treat with different trees, leaves, stones, etc. The kabiraz also provide amulet to tie at the arms or put on the neck.

\section{Trade Union}

Formation of a trade union to protect the rights of the laborer is a mandatory provision. A trade union exists in the Malnichara tea garden. However, it is claimed that the union is not functional and does not play any role for the welfare of the workers. Some of the participants commented that 'we have a trade union in name only; no one saw its activities.' Majority of the respondents $(85.33 \%)$ do not have its membership. However, only 14.67 percent workers acknowledged their membership with the trade union.

One of the respondents reported that "trade union activities are unseen in our garden. Union leaders have a relationship with the garden authority. They served their interest using the union. Some of the leaders even receive the bribe from the authority to suppress the labor movement in the garden."

Though most of the respondents are not satisfied with the activities of the trade union, a small number of them $(33.33 \%)$ narrated the success story of the union. They opined that the wages of the workers increased from Tk. 48 to Tk. 55 due to the movement of the union. Nevertheless, they want more visible activities of the union to ensure the welfare of the tea garden workers. 
Table-9: Satisfaction on trade union

\begin{tabular}{lll}
\hline Status & Frequency & Percentage $\mathbf{( \% )}$ \\
\hline Satisfied & 25 & 33.33 \\
Not satisfied & 36 & 47.00 \\
Neutral & 14 & 18.67 \\
\hline Total & $\mathbf{7 5}$ & $\mathbf{1 0 0}$ \\
\hline
\end{tabular}

(Source: Field Survey, April-July, 2014)

\section{Participation in Mainstream Politics}

Constitution of the People's Republic of Bangladesh guaranteed equal rights of its citizen irrespective of ethnicity, race, language, religion and geographic location. However, tea garden workers seemed discriminated in various aspects including political participation compared to mainstream Bangalee population.

This study indicated that most of the tea garden workers (78.67\%) are not involved with any political parties in Bangladesh. Only 16 workers informed their political involvement, though 14 are only the supporter. It means that only $2(2.67 \%)$ have actively participated in politics. However, we did not find any tea garden workers participated in the political decision making.

Table-10: Political participation

\begin{tabular}{lllll}
\hline Variables & Nature of participation & & Percentage (\%) \\
\hline Involved with politics & Supporter & Activists & Total & 21.33 \\
& 14 & 2 & 16 & \\
Not involved with politics & 59 & & & 78.67 \\
& & & & 100 \\
\hline Total & 75 &
\end{tabular}

(Source: Field Survey, April-July, 2014)

Most of the tea garden workers are not aware of the political activities of the country. Some of them said, 'politics is a matter of those who have enough money; it is not for the workers'. They know the name of 'Sheikh Hasina', 'Khaleda Zia' and Ershad. Nevertheless, they even do not know the name of the President of the country. It is known that some of the respondents do not even vote at the election. However, most of them vote at the local government and national elections.

\section{Conclusion and Policy Implications}

The tea garden workers have a significant contribution to the national economy by boosting tea production. However, it is ironic that they are struggling for the survival with a meager wage and minimum service provisions in the garden. They are discriminated and disadvantaged ethnic groups who even do not have the power to bargain and fight for their rights. It is not possible to ensure sustainable development in the country leaving this ethnic group marginalized and discriminated. Their inclusion in mainstream society and providing access to education, healthcare, employment, and political process will ensure an equitable society. Towards this end, the following measures might be undertaken by the government and NGOs working in the tea gardens:

Education needs to be ensured for the children living in the tea garden. Secondary schools have to be established so that the dropout after completion of primary education can be minimized. In addition, stipends for the tea garden children should be provided to encourage them towards education and motivate the parents for continuing education of their children.

Wages for the tea garden workers need to be increased. The Government can influence the tea garden authority to offer a wage that may suffice to maintain the family with mitigating minimum basic needs. 
The authority of the garden should ensure healthcare provision in the garden with skilled doctors, nurses, and support staffs. It should be ensured that health professionals positively accept them and behave professionally. Moreover, sanitation system in the gardens needs to be improved.

Compulsory and free primary education in the garden need to be appropriately implemented. The increasing literacy rate will control child labor in the garden and, in turn, it will ensure human resource development in the gardens.

The trade union in the garden should be functional and useful. Union leaders need to be educated so that they fight for the welfare of the garden workers. Furthermore, the campaign to make the workers aware of their rights and responsibility might be initiated to develop their political consciousness and political involvement.

\section{References}

Ahmed, M., Begum, A., \& Chowdhury, M. A. I. (2010). Social constraints before sanitation improvement in tea gardens of Sylhet, Bangladesh. Environ Monit Assess, 164, 263-271. doi:10.1007/s10661-009-0890-0

Al-Amin, M., Hossain, M. I., \& Parveen, S. S. (2017). Social Exclusion and Poverty among Tea Garden Workers in Bangladesh. The Indian Journal of Industrial Relations, 53(1), 21-36.

Barkat, B., Mahiyuddin, G., Shaheen, N., Poddar, A., Osman, A., Rahman, M., \& Ara, R. (2010). Assessment of the situation of children and women in the tea gardens of Bangladesh. Dhaka: Planning, Monitoring \& Evaluation Section, UNICEF.

Chowdhury, M. A. I., Hasan, G. M. J., \& Karim, M. A. (2011). A study on existing WATSAN condition of two tea gardens in Maulvibazar. Journal of Environ. Sci. \& Natural Resources, $4(2), 13-18$.

Das, T. K., \& Islam, S. M. H. Z. (2006). Human rights of the tea gardeners: Case study of selected gardens in Sylhet. Asian Affairs, 28(3), 25-39.

Hossain, M. I., Al-Amin, M., \& Parveen, S. S. (2017). Protection of Child Rights in Tea Gardens of Bangladesh: Social Work Perspective. Social Work Chronicle, 6(1), 39-53. 